\title{
Peran Orang Tua Dalam Mengembangkan Kecerdasan Emosional Anak di Desa Petonggan Kecamatan Rakit Kulim Kabupaten Indragiri Hulu
}

\author{
SYAHRAINI TAMBAK* \\ M. YUSUF AHMAD** \\ HELMAN $* * *$ \\ *Fakultas Agama Islam (FAI) Universitas Islam Riau (UIR) Pekanbaru \\ Jl. Kaharuddin Nasution, No. 113, Perhentian Marpoyan Pekanbaru 28284 \\ e-mail: syahraini_tambak@yahoo.co.id \\ ** Fakultas Agama Islam (FAI) Universitas Islam Riau (UIR) Pekanbaru \\ Jl. Kaharuddin Nasution, No. 113, Perhentian Marpoyan Pekanbaru 28284. Hp. 081365542760 \\ ***Fakultas Agama Islam (FAI) Universitas Islam Riau (UIR) Pekanbaru \\ Jl. Kaharuddin Nasution, No. 113, Perhentian Marpoyan Pekanbaru 28284
}

\begin{abstract}
Abstrak: Kecerdasan emosional merupakan salah satu kecerdasan yang sangat mempengaruhi perkembangan kehidupan anak, karena 80\% kesuksesan kehidupan sangat ditentukan oleh kecerdasan emosional. Memberikan pendidikan kepada anak sejak dini merupakan hal yang sangat penting dan sangat dianjurkan karena sejak anak dilahirkan hingga tahun-tahun pertama, anak akan mengalami pertumbuhan dan perkembangan yang pesat. Perkembangan anak pada tahuntahun awal lebih kritis dibandingkan dengan perkembangan selanjutnya, sehingga dapat disimpulkan bahwa masa kanak-kanak merupakan gambaran awal manusia sebagai manusia seutuhnya. Peran orang tua dalam perkembangan emosional anak sangat dibutuhkan, karena orang tualah yang dapat mendampingi dan mengembangkan kecerdasan anak semaksimal mungkin. Perkembangan anak khususnya perkembangan emosionalnya tercapai dengan baik dan sempurna. Tujuan penelitian ini adalah untuk mengetahui Peran Orang Tua Dalam Mengembangkan Kecerdasan Emosional Anak di Desa Petonggan Kecamatan Rakit Kulim Kabupaten Indragiri Hulu. Penelitian ini menggunakan metode deskriptif kuantitatif. Populasi dalam penelitian ini adalah seluruh orang tua yang mempunyai anak usia 7-14 tahun yang berjumlah 122 kepala keluarga. Karena besarnya jumlah populasi dalam penelitian ini, maka penulis mengambil $50 \%$ dari jumlah populasi yaitu sebanyak 61 kepala keluarga. Teknik analisis data yang digunakan dalam penelitian ini adalah deskriptif kuantitatif yaitu dengan menggambarkan data yang berwujud angka-angka hasil perhitungan dan pengukuran dapat diproses dengan cara dijumlahkan. Dari hasil penelitian ini, dapat diketahui bahwa Peran Orang Tua dalam mengembangkan kecerdasan emosional anak di Desa Petonggan Kecamatan Rakit Kulim Kabupaten Indragiri Hulu pada taraf "76,04\%" yaitu berada pada rentang 61\%-80\% dikategorikan "Baik".
\end{abstract}

Kata kunci: Peran Orang Tua, Kecerdasan Emosional, Anak. 


\section{PENDAHULUAN}

Islam memandang, bahwa keluarga merupakan lingkungan yang paling berpengaruh pada pembentukan kepribadian anak. Hal ini disebabkan karena tanggung jawab orang tua pada anak tidak hanya bersifat duniawi, melainkan ukhrawi. Tugas dan tanggung jawab orang tua dalam membina kepribadian anak merupakan amanah dari Tuhan. Orang tua di samping memberikan pengaruh yang bersifat empiris setiap hari, juga memberikan pengaruh yang genesitas, yakni bakat dan pembawaan serta hubungan darah yang melekat pada diri anak. Seorang anak lazimnya lebih banyak tinggal di rumah dari pada di luar rumah, sehingga orang tua atau keluarga sebagai inilah yang lebih dahulu pengaruhnya lebih kuat dibandingkan dengan pengaruh yang datang belakangan (Nata, 2010 : 299).

Dalam pandangan Islam, manusia adalah makhluk ciptaan Allah yang di dalamnya diberi kelengkapan psikologis dan fisik yang memiliki kecendrungan kearah yang baik dan yang buruk. Manusia sejak ajali adalah manusia. Tetapi yang diusahakan dimanusiakan melalui proses pendidikan adalah sikap dan prilakunya. Untuk mencapai keinginan tersebut, peranan orang dewasa orang tua dalam keluarga yang taat ajaran agama sangat menentukan dalam pendidikan anak. Dari sini dapat dipahami, bahwa hakikat pendidikan islam adalah usaha orang dewasa muslim yang bertaqwa secara sadar mengarahkan dan membimbing pertumbuhan serta perkembangan fitrah (kemampuan dasar) anak didik melalui ajaran islam kearah titik maksimal pertumbuhan dan perkembangannya (Djamarah, 2004: 74-75).

Selain itu, Ramayulis (2008 : 18) mendefinisikan bahwa pendidikan adalah usaha sadar yang dilakukan keluarga, sekolah, masyarakat dan pemerintah melalui kegiatan bimbingan pengajaran dan latihan yang diselenggarakan di lembaga pendidikan formal, non formal, in formal dan dilaksanakan sepanjang hayat, dalam rangka mempersiapkan anak agar berperan dalam berbagai kehidupan.

Lingkungan keluarga merupakan lingkungan pendidikan yang pertama, karena dalam keluarga inilah anak pertama mendapatkan pendidikan dan bimbingan. Juga dikatakan lingkungan yang utama, karena sebagian besar dari kehidupan anak adalah di dalam keluarga, sehingga pendidikan yang paling banyak diterima oleh anak adalah dari dalam keluarga. Tugas utama keluarga bagi pendidikan anak adalah sebagai peletak dasar pendidikan akhlak dan pandangan hidup keagamaan. Sifat dan tabiat anak sebagian besar diambil dari kedua orang tuanya dan dari anggota keluarga yang lain (Hasbullah, 2009 : 38).

$\begin{array}{ccr}\text { Pendidikan dalam } & \text { keluarga } \\ \text { memiliki nilai } & \text { strategis dalam }\end{array}$ pembentukan kepribadian anak. Sejak kecil anak sudah mendapat pendidikan dari kedua orang tua melalui keteladanan dan kebiasaan hidup sehari-hari dalam keluarga. Baik tidaknya keteladanan yang diberikan dan bagaimana kebiasaan hidup orang tua sehari-hari dalam keluarga akan mempengaruhi perkembangan jiwa anak. Meniru kebiasaan hidup orang tua adalah suatu hal yang sering anak lakukan, karena memang pada masa perkembangannya, anak selalu menuruti apa-apa yang orang tua lakukan. Anak selalu meniru ini dalam pendidikan dikenal dengan istilah anak belajar melalui imitasi (Djamarah, 2004: 24-25).

Pendidik dalam lingkungan keluarga adalah orang tua. Hal ini disebabkan karena secara alami anakanak pada masa awal kehidupan 
berada di tengah- tengah ayah dan ibunya. Dari merekalah anak mulai mengenal pendidikannya. Dasar pandangan hidup, sikap hidup dan keterampilan hidup banyak tertanam sejak anak berada di tengah orang tuanya. Bahkan, dalam Al-Qur'an juga menyebutkan bahwa orang tua sebagai guru, dan disebut juga pendidik kudrati yaitu yang telah diciptakan oleh Allah qudratnya sebagai pendidik (Ramayulis, $2008: 60$ ).

\section{Allah SWT berfirman:}

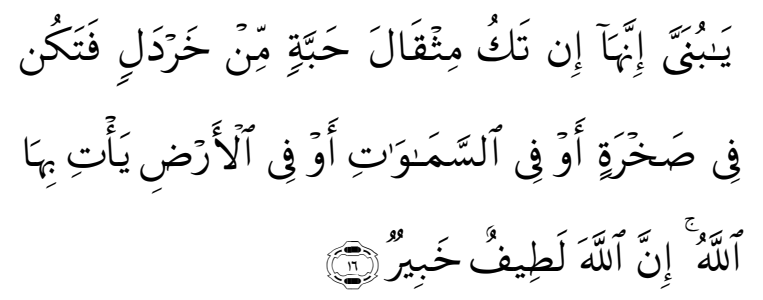

Artinya :"(Lukman berkata)" Hai anakku, sesungguhnya jika ada (sesuatu perbuatan) seberat biji sawi, yang berada dalam batu atau di langit ataupun di dalam bumi, niscaya Allah akan mendatangkannya (membalasinya) sesungguhnya Allah maha halus lagi maha mengetahui." (QS. Luqman, 31: 16).

Dari ayat di atas jelas sekali bahwa keluarga atau orang tua harus bertanggung jawab memberikan pendidikan kepada anaknya dengan pendidikan yang baik berdasarkan nilai-nilai akhlak dan spiritual yang luhur, namun sayangnya tidak semua orang tua yang dapat melakukannya. Buktinya di masyarakat sering ditemukan anak-anak nakal dengan sikap dan prilaku (Djamarah, 2004 : 31).

Demikianlah betapa pentingnya pendidikan dalam lingkungan keluarga bagi perkembangan anak menjadi manusia yang berpribadi dan berguna bagi masyarakat. Karena orang tua mengutamakan kepentingan dan kebutuhan anaknya.

Sedangkan fungsi orang tua itu sendiri berkaitan langsung dengan pemberi rasa aman bagi anak, sumber pemenuhan kebutuhan, sumber kasih sayang dan penerimaan, model pola prilaku yang tepat bagi anak untuk belajar menjadi baik, pemberi bimbingan bagi pengembangan prilaku yang secara sosial dianggap tepat, pembentukan penyesuaian diri anak, pemberi bimbingan belajar, pembentukan pengembangan kemampuan, pembimbing dalam mengembangankan aspirasi, sumber persahabatan (Yusuf, 2011 : 38-39).

Allah SWT berfirman:

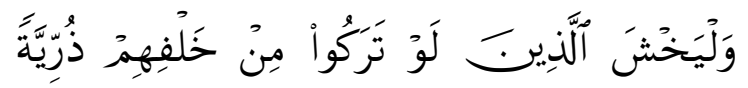

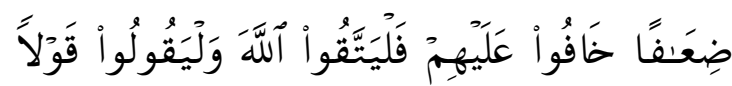
سَدِيدًا

Artinya :"Dan hendaklah takut kepada Allah, orang-orang yang seandainya meninggalkan di belakang mereka anak-anak yang lemah (iman, ilmu dan amal), yang mereka khawatir terhadap kesejahteraan, oleh sebab itu hendaklah mereka bertaqwa kepada Allah dan hendaklah mereka mengucapkan perkataan yang benar" (QS. An-Nisa', 4: 9).

Ayat di atas mengisyaratkan kepada orang tua agar tidak meninggalkan anak mereka dalam keadaan lemah. Lemah yang dimaksud ialah lemah dalam segala aspek terutama sekali lemah iman. Anak yang lemah imannya akan menjadi generasi tanpa kepribadian. Jadi semua orang tua harus memperhatikan semua aspek perkembangan anaknya baik itu dari segi perhatian, kasih sayang 
maupun masalah aqidah atau keimanannya. Demi pendidikan yang akan mempunyai potensi yang beragama, maka para orang tua hendaknya memberikan pendidikan agama tersebut dengan baik, berlaku lemah lembutnya kepada anak, karena dengan berperilaku demikian akan sangat membantu merubah personalitas kepribadiannya.

Dari pendapat di atas, dapat dipahami bahwa peranan orang tua merupakan hal yang sangat penting sekali terutama dalam mengembangkan kecerdasan emosional anak dalam keluarga, apalagi untuk masa yang akan datang. Namun, di Desa Petonggan Kecamatan Rakit Kulim Kabupaten Indagiri Hulu masih terdapat gejalagejala sebagai berikut : (a) Masih kurangnya kesadaran diri pada diri anak, seperti : berkelahi; (b) Masih ada anak yang belum bisa mengontrol dirinya sendiri, seperti : marah yang berlebihan; (c) Masih ada anak yang belum bisa menerima diri sendiri, seperti : memandang diri sendiri dengan pandangan negatif; dan (d) Masih ada anak yang suka berbohong dan tidak jujur dalam berbuat, seperti : anak mengambil uang orang tua.

Berdasarkan gejala di atas penulis tertarik untuk mengadakan penelitian dengan judul : "PERAN ORANG TUA DALAM MENGEMBANGKAN KECERDASAN EMOSIONAL ANAK DI DESA PETONGGAN KECAMATAN RAKIT KULIM KABUPATEN INDRAGIRI HULU". Mengingat banyaknya masalah yang diteliti serta terbatasnya kemampuan, maka penulis membatasi masalah hanya pada "Peranan Orang Tua dalam Mengembangkan Kecerdasan Emosional Anak di Dusun I, Dusun IV, dan Dusun V Desa Petonggan Kecamatan Rakit Kulim Kabupaten Indragiri Hulu". Adapun yang menjadi rumusan masalah dalam penelitian ini adalah : "Bagaimana Peranan Orang Tua dalam
Mengembangkan Kecerdasan Emosional Anak di Desa Petonggan Kecamatan Rakit Kulim Kabupaten Indragiri Hulu?". Adapun yang menjadi tujuan penelitian ini adalah : Untuk Mengetahui Peran Orang Tua dalam Mengembangkan Kecerdasan Emosional di Dusun I, Dusun IV, dan Dusun V Desa Petonggan. Hasil penelitian ini diharapkan dapat pula bermanfaat untuk : (1) Sebagai sumbangan ilmu secara umum bagi orang tua dalam keluarga untuk mengembangkan kecerdasan emosional bagi anak; (2) Sebagai acuan dalam perkembangan ilmu pendidikan tentang kecerdasan emosional anak; dan (3) Sebagai sumbangan pemikiran penulis dalam bidang pendidikan agama islam.

\section{KONSEP TEORI \\ Hakikat Peranan Orang Tua}

Dalam kamus besar bahasa Indonesia (2008), pengertian peranan adalah: (1) Bagian yang dimainkan seorang pemain (di film, sandiwara $\mathrm{dsb}$ ), ia berusaha bermain baik disemua yang dibebankan kepadanya; dan (2) Tindakan yang dilakukan oleh seseorang disuatu peristiwa.

Keluarga merupakan lingkungan pertama bagi anak, di lingkungan keluarga pertama sekali anak mendapatkan pengaruh sadar. Karena itu keluarga merupakan lembaga pendidikan tertua, yang bersifat informal dan kodrati. Lahirnya keluarga sebagai lembaga pendidikan semenjak manusia itu ada. Ayah dan ibu di dalam keluarga sebagai pendidiknya. Keluarga merupakan lembaga pendidikan tidak mempunyai program yang resmi seperti yang dimiliki oleh lembaga pendidikan formal. Tugas keluarga adalah meletakkan dasar-dasar bagi perkembangan anak berikutnya, agar anak dapat berkembang secara baik. Keluarga sebagai lingkungan pendidikan yang pertama sangat 
penting dalam membentuk pola kepribadian anak. Karena di dalam keluarga anak pertama kali berkenalan dengan nilai dan norma (Ihsan, 2005 : 17).

$\begin{array}{ccr}\text { Menurut } & \mathrm{Ki} \text { Hajar } & \text { Dewantara, } \\ \text { menyatakan } & \text { bahwa } & \text { keluarga }\end{array}$
merupakan "pusat pendidikan" yang pertama dan terpenting karena sejak timbulnya adab kemanusiaan sampai kini, keluarga selalu mempengaruhi pertumbuhan budi pekerti tiap-tiap manusia. Di samping itu orang tua dapat menanamkan benih kebatinan sesuai dengan kebatinannya sendiri ke dalam jiwa anak-anaknya. Inilah hak orang tua yang pertama yang tidak bisa dibatalkan oleh orang lain (Shochib, 2010 : 10).

Orang tua merupakan pendidik utama dan pertama bagi anak-anak mereka, karena dari merekalah anak mula-mula menerima pendidikan. Dengan demikian bentuk pertama dari pendidikan terdapat dalam kehidupan keluarga (Daradjat, 2012 : 35).

Keluarga mempunyai peranan

yang sangatpenting dalam upaya mengembangkan pribadi anak. Perawatan orang tua yang penuh kasih sayang dan pendidikan tentang nilainilai kehidupan, baik agama maupun sosial agama ataupun sosial budaya yang diberikannya merupakan faktor yang kondusif untuk mempersiapkan anak menjadi pribadi dan anggota masyarakat yang sehat. Apabila mengaitkan peranan keluarga dengan upaya memenuhi kebutuhan individu, maka keluarga merupakan lembaga pertama yang dapat memenuhi kebutuhan tersebut. Melalui perawatan dan perlakuan yang baik dari orang tua anak dapat memenuhi kebutuhankebutuhan dasarnya, baik fisik biologis maupun sosio psikologisnya (Yusuf, 2011 : 37-38).

Allah SWT berfirman:

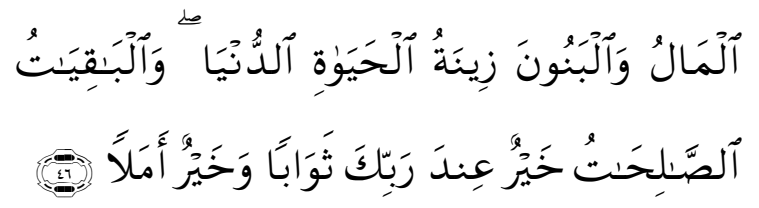

Artinya : "Harta dan anak-anak adalah
perhiasan kehidupan dunia
tetapi amalan-amalan yang
kekal lagi shaleh adalah lebih
baik pahalanya di sisi
Tuhanmu serta lebih baik
untuk menjadi harapan" (QS.
Al-Kahfi, 18: 46).

Peranan keluarga merupakan lembaga pendidikan yang pertama dan utama dalam masyarakat, karena dalam keluargalah manusia dilahirkan, berkembang menjadi dewasa. Bentuk dan isi serta cara-cara pendidikan di dalam keluarga akan selalu mempengaruhi tumbuh dan berkembangnya watak, budi pekerti dan kepribadian tiap-tiap manusia (Ihsan, 2005 : 57).

Adapun peran orang tua terhadap pendidikan anak, yaitu : (a) Memelihara dan membesarkan anak. Ini adalah bentuk yang paling sederhana dari tanggung jawab setiap orang tua; (b) Melindungi dan menjamin kesamaan, baik jasmani maupun rohaniah; (c) Memberikan pengajaran dalam arti yang luas sehingga anak memperoleh peluang untuk memiliki pengetahuan dan kecakapan; dan (d) Membahagiaakan anak, baik dunia maupun akhirat, sesuai dengan pandangan dan tujuan hidup muslim (Djamarah, 2004 : 86-87)

Keluarga ialah ikatan laki-laki dengan wanita berdasarkan hukumhukum atau undang-undang perkawinan yang sah. Di dalam keluarga ini lahirlah anak- anak. Di sinilah terjadi pendidikan. Para ahli didik umumnya menyatakan, pendidikan di lembaga ini merupakan pendidikan pertama dan utama. Dikatakan demikian karena di 
lembaga inilah anak-anak mendapatkan pendidikan untuk pertama kalinya. Di samping itu pendidikan di sini mempunyai pengaruh dalam terhadap kehidupan peserta didik dikelak kemudian hari (Sudiyono, 2009 : 301). Allah SWT berfirman:

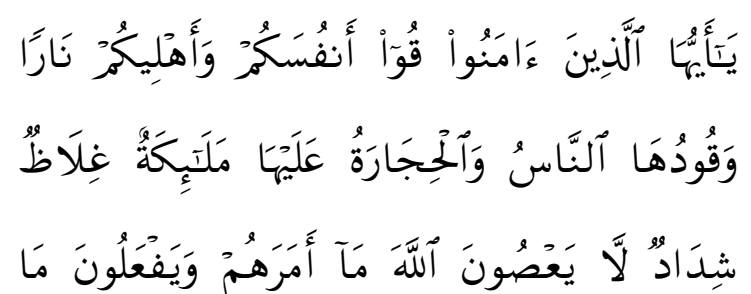
يُوَّحُونَونَ

Artinya : "Hai orang-orang yang beriman, peliharalah dirimu dan keluargamu dari api neraka yang bahan bakarnya adalah manusia dan batu, penjaganya malaikatmalaikat yang kasar, keras, dan tidak mendurhakai Allah terhadap apa yang diperintahkan-Nya kepada mereka dan selalu mengerjakan apa yang diperintahkan." (QS. AtTahrim, 66: 6).

Demikian beberapa hal yang perlu diperhatikan sebagai peran orang tua terhadap anaknya, terutama dalam konteks pendidikan. Kesadaran akan tanggung jawab mendidik dan membina anak secara terus-menerus perlu dikembangkan kepada setiap orang tua, sehingga pendidikan yang dilakukan tidak lagi berdasarkan kebiasaan yang dilihat dari orang tua, tapi telah didasari oleh teori-teori pendidikan modern, sesuai dengan perkembangan zaman.

Dimulai dengan pengenalan akan pentingnya pendidikan anak, metode pendidikan anak sejak dalam kandungan, lalu sejak anak berusia 0-7 dan saat berusia 7-14 dan 14-21 tahun disajikan dengan tutur yang enak dibaca dan mudah diterapkan dengan landasan pemahaman yang untuk setiap orang tua peduli akan kecermelangan masa depan putra-putrinya (Yusuf, $2011: 20$ )

Dari pengertian di atas dapat diperoleh gambaran bahwa keluarga dan pendidikan adalah dua istilah yang tidak dapat dipisahkan sebab dimana ada keluarga disitu ada pendidikan. Sebab keluarga adalah sebuah institusi pendidikan yang utama dan bersifat kodrati. Sebagai komunitas masyarakat terkecil, keluarga memiliki arti penting dan strategis dalam pembangunan komunitas masyarakat yang lebih luas. Untuk itu interaksi yang kondusif perlu dibangun sehingga pendidikan dapat berlangsung dengan baik, pendidikan dasar yang baik harus diberikan kepada anggota keluarga dalam upaya memerankan fungsi pendidikan dalam keluarga, yaitu menumbuhkembangkan potensi laten anak, sebagai wahana untuk menstransfer nilai-nilai dan sebagai agen transformasi kebudayaan (Djamarah, 2004 : 3).

Anak pada dasarnya makhluk yang lemah, harus dibimbing dan dibina dalam menyesuaikan diri dalam realitas hidup dan lingkungan yang ada sehingga dapat beradaptasi dengan berbagai perubahan, menghargai tata aturan etika, sopan santun, serta tidak liar, baik secara sosial maupun alami. Pengertian ini menandakan ada potensi yang dapat dididik pada diri seorang anak, dengan kata lain anak adalah makhluk yang dapat diberi pelajaran atau pendidikan.

Menurut Aristoteles, perkembangan individu sejak anak sampai dewasa itu ke dalam tiga tahapan, yaitu : 0-7 tahun adalah masa anak kecil atau masa bermain, 7-14 tahun adalah masa anak, masa sekolah rendah, 14-21 tahun adalah masa remaja atau masa pubertas, masa peralihan dari usia anak menjadi orang dewasa (Yusuf, $2011: 20$ ). 
Mengenai beberapa batasan usia penulis maksudkan dalam kajian ini adalah masa anak yaitu mulai dari usia 7-14 tahun, usia ini dipilih dengan asumsi jika anak mempunyai orang tua muslim yang baik, mengajarkan dirinya kepada prinsip-prinsip Islam, maka ia akan tumbuh dan berkembang dalam nuansa keislaman.

\section{Bentuk-bentuk Peran Penting Orang Tua}

Peranan penting orang tua adalah sebagai lembaga pendidikan. Peranan keluarga terutama dalam penanaman sikap dan nilai hidup, mengembangkan bakat dan minat serta pembinaan bakat dan kepribadian. Sehubungan dengan itu penanaman dan nilai-nilai pancasila, nilai-nilai keagamaan dan nilai-nilai kepercayaan terhadap Tuhan Yang Maha Esa dimulai dalam keluarga. Agar keluarga dapat memainkan peran tersebut, keluarga perlu juga bekali dengan pengtahuan dan keterampilan pendidikan, perlu adanya pembinaan. Hal ini dapat dicapai melalui pendidikan orang dewasa (Ihsan, 2005 : 58).

Adapun bentuk-bentuk peranan orang tua terhadap anak sebagaimana dikemukakan oleh beberapa ahli sebagai berikut: (1) Melatih anak belajar disiplin; (2) Membiasakan diri berprilaku sesuai dengan nilai-nilai berdasarkan acuan moral; dan (3) Perlu adanya kontrol orang tua untuk mengembangkannya (Shochib, 2010 : 21).

Keluarga merupakan lingkungan pendidikan tertua, bersifat informal, yang pertama dan utama dialami oleh anak dan lembaga pendidikan yang bersifat kodrati, karena orang tua memiliki tanggung jawab yang besar dalam perkembangan anak dengan baik. Lembaga pendidikan keluarga memberikan pengalaman pertama merupakan faktor penting dalam perkembangan pribadi anak. Suasana pendidikan dalam keluarga ini sangat penting diperhatikan, sebab dari sinilah keseimbangan jiwa dalam perkembangan individu selanjutnya ditentukan. Atas dasar itu upaya mewujudkan akhlak yang baik bagi anak dalam proses pendidikannya diperlukan pendidikan komunikasi islami untuk membentuk kepribadian dalam keluarga dengan baik serta mengetahui fungsi dan peranannya dalam pendidikan (Tambak, 2013 : 12).

Dengan adanya kesadaran akan tanggung jawab mendidik dan membina anak secara kontinue perlu dikembangkan kepada setiap orang tua sehingga pendidikan yang dilakukan tidak lagi berdasarkan kebiasaan yang dilihat dari orang tua, tetapi telah didasari oleh teori-teori pendidikan modern, sesuai dengan perkembangan zaman yang cendrung sering berubah. Tugas utama keluarga bagi pendidikan anak ialah sebagai peletak dasar bagi pendidikan akhlak dan pandangan hidup keagamaan. Sifat dan tabiat anak sebagian besar diambil dari kedua orang tuanya dan dari anggota keluarga lain (Hasbullah, 2009 : 89).

Pendidikan dalam keluarga memberikan keyakinan agama, nilai budaya yang mencakup nilai moral dan aturan-aturan pergaulan serta pandangan, keterampilan dan sikap hidup yang mendukung kehidupan masyarakat, berbangsa dan bernegara kepada anggota keluarga yang bersangkutan.

\section{Konsep Kecerdasan Emosional}

Emosi itu dapat didefinisikan sebagai suatu suasana yang kompleks (a complex feeling state) dan getaran jiwa (a stird up state) yang menyertai atau muncul sebelum/sesudah terjadinya perilaku. Gejala-gejala seperti takut, cemas, marah, dongkonl, iri, 
cemburu, senang, kasih sayang, simpati, dan sebagainya merupakan beberapa proses menifestasi dari keadaan emosional pada diri seseorang (Nurihsan dan Agustin, 2011 : 33).

EQ atau Emosional Quotient merupakan kemampuan pengendalian diri, nafsu, dan emosi dan penegetauan tentang dirinya sendiri. Mengetahui diri sendiri yang dimaksud di sini bukanlah diri yang bersifat fisik, seperti tinggi badan, warna kulit, dan sebagainya, tetapi berkenaan dengan fenomenafenomena kedirian. Mengetahui potensipotensi dan kemampuan yang dimiliki sendiri, mengetahui kelemahankelemahan dan juga perasaan dan emosi. Dengan seperti itu seseorang mestinya mendayagunakan, menegekspresikan, mengendalikan dan juga mengkomunikasikan dengan pihak pihak lain. Orang yang memiliki kecerdasan emosional adalah empati (memahami orang lain secara mendalam), mengungkapkan dan memahami perasaan, mengendalikan amarah, kemandirian, kemampuan menyesuaikan diri, disukai, kemampuan memecahkan masalah, kesetiakawanan, keramahan dan sikap hormat. Sedangkan kunci kecerdasan emosional adalah kesabaran (Djamarah, 2004 : 131-133).

Perkembangan emosi pada masa pertumbuhan anak semangkin lama semangkin halus dalam mengepresikannya sampai masa remaja. Peralihan ekspresi emosi yang tadinya kasar, karena terpengaruh latihan dan kontrol, berangsur-angsur tingkah laku emosionalnnya berubah. Sebagai

orang tua dan guru sebaiknya bisa menyadari bahwa anak pada masa pertumbuhan masih membutuhkan stimuasi (rangsangan) yang positif bagi perkembangan emosional selanjutnya. Selama anak bertambah kekuatan fisik dan pengertiannya, ia akan merespon dengan cara yang berbeda beda terhadap segala sesuatunya, karena sudah terlebih dahulu dipertimbangkannya (Djaali, 2012: 39 ).

Emosi merupakan perasaan yang paling mendasar yang dialami seseorang. Hal ini ia gambarkan dalam bentuk kebahagiaan dan kemarahan. Emosi dan motif memiiki hubungan yang erat, yaitu emosi dapat mengangtifkan dan mengarahkan prilaku dalam cara yang sama seperti yang dilakukan motif dasar. Emosi juga dapat menyertai perilaku termotivasi (Latipah, 2012 : 191-192).

Peranan keluarga sebagai lembaga pendidikan semangkin tampak penting. Peranan keluarga terutama dalam penanaman sikap dan nilai hidup, pengembangan bakat dan minat serta pembinaan bakat dan kepribadian. Sehubungan dengan itu penanaman nilai-nilai pancasila, nilai-nilai keagamaan dan nilai-nilai kepercayaan terhadap tuhan yang Maha Esa dimulai dalam keluarga. Agar keluarga dapat memainkan peran tersebut, keluarga perlu juga bekali dengan pengetahuan dan keterampilan pendidikan, perlu adanya pembinaan (Ihsan, 2005 : 58).

Orang tua memegang peranan utama dan memikul tanggung jawab pendidikan anak. Pada saat ini pemeliharaan dan pembiasaan sangat penting dalam pelaksanaan pendidikan. Kasih sayang orang tua yang tumbuh akibat dari hubungan darah dan diberikan kepada anak secara wajar atau sesuai dengan kebutuhan, mempunyai arti sangat penting bagi pertumbuhannya. Karena itu orang tua harus pandai dan tepat memberikan kasih sayang kepada anaknya jangan kurang dan jangan pula berlebihan (Sudiyono, $200: 301$ ).

Adapun peran orang tua dalam mengembangkan emosi pada anak menurut Daniel Goleman yaitu: (1) Belajar mengembangkan kesadaran diri, 
dengan cara mengamati diri sendiri dan mengenali perasaan sendiri, menghimpun kosakata untuk mengungkapkan perasaan, serta memahami hubungan antara pikiran, perasaan dan respons emosional; (2) Belajar mengambil keputusan pribadi, dengan cara mencermati tindakantindakan dan akibat-akibatnya, memahami apa yang menguasai suatu keputusan, pikiran atau perasaan, serta menerapkan pemahaman ini kemasalah-masalah yang cukup berat; (3) Belajar mengelola perasaan, dengan cara memantau pembicaraan sendiri untuk menangkap pesan-pesan negatif yang terkandung di dalamnya, menyadari apa yang ada di balik perasaan; (4) Belajar menangani sters, dengan cara mempelajari pentingnya olah raga, perenungan yang terarah dan metode relaksasi; (5) Belajar berempati, dengan cara memahami perasaan dan masalah orang lain, berfikir dengan sudut pandang orang lain serta menghargai perbedaan perasaan orang lain mengenai sesuatu; (6) Belajar berkomunikasi, dengan cara berbicara mengenai perasaan secara efektif yaitu belajar menjadi pendengar dan penanya yang baik, membedakan antara apa yang dilakukan atau yang dikatakan seseorang dengan reaksi atau penilaian sendiri tentang sesuatu, serta mengirimkan pesan yang sopan; (7) Belajar membuka diri, dengan cara menghargai keterbukaan dan membina kepercayaan dalam suatu hubungan serta mengetahui situasi yang aman untuk membicarakan tentang perasaan diri sendiri; (8) Belajar mengembangkan pemahaman, dengan cara mengidentifikasi pola-pola kehidupan emosional dan reaksireaksinya serta mengenali pola-pola serupa pada orang lain; (9) Belajar menerima diri sendiri, dengan cara merasa bangga dan memandang diri sendiri dengan positif, mengenali kekuatan dan kelemahan diri sendiri; (10) Belajar mengembangkan tanggung jawab pribadi, dengan cara belajar rela memikul tanggung jawab, mengenali akibat-akibat dari keputusan dan tindakan pribadi serta menindak lanjuti komitmen yang telah dibuat dan disepakati; (11) Belajar mengembangkan ketegasan, dengan cara mengungkapkan keprihatinan dan perasaan sendiri; (12) Mempelajari dinamika kelompok, dengan cara mau bekerja sama, memahami kapan dan bagaimana memimpin, serta memahami kapan harus mengikuti; dan (13) Belajar menyelesaikan konflik, dengan cara memahami bagaimana melakukan konfrontasi secara jujur dengan orang lain, orang tua atau guru serta memahami cara menyelesaikan suatu konflik (Al-Migwar, 2006 : 209-210).

Untuk mencapai tujuan itu, orang tualah yang menjadi pendidik pertama dan utama, kaidah ini diterapkan secara kodrati, artinya orang tua tidak dapat berbuat lain dan harus siap, mau tidak mau mereka yang harus menjadi penanggung jawab yang pertama dan utama. Jadi penting sekali peran orangtua untuk membantu anaknya terutama dalam mencerdaskan kemampuan emosionalnya, maka dengan begitu kecerdasan anak akan seimbang dan dapat membantu dalam mewujudkan masa depannya yang cerah nantinya.

Keluarga merupakan pendidikan pertama atau dasar. Anak lahir dalam pemeliharaan orang tua dan dibesarkan dalam keluarga. Orang tua tanpa ada yang memerintah langsung memikul tugas sebagai pendidik, baik bersifat sebagai pemelihara, sebagai pengasuh, sebagai pembimbing, sebagai pembina maupun sebagai guru dan pemimpin terhadap anak-anaknya. Ini adalah tugas kodrati dari tiap-tiap manusia. Orang tua adalah pemimpin keluarga, sebagai 
penanggung jawab atas keselamatan keluarganya di dunia khususnya di akhirat. Maka orang tua wajib mendidik anaknya (Ahmadi dan Uhbiyati, 2003 : 177-178).

Jelaslah bahwa keluarga itu merupakan ajang pertama dimana sifatsifat kepribadian anak bertumbuh dan terbentuk. Seseorang akan menjadi warga masyarakat yang baik sangat tergantung pada sifat-sifat yang tumbuh dalam kehidupan keluarga dimana anak dibesarkan. Kelak kehidupan anak tersebut juga mempengaruhi masyarakat sekitarnya sehingga pendidikan keluarga itu merupakan dasar terpenting dalam kehidupan anak sebelum masuk sekolah dan terjun ke dalam masyarakat. Karena keluarga adalah merupakan ajang dimana sifatsifat kepribadian anak terbentuk mula pertama, maka dapatlah dengan tegas dikatakan bahwa keluarga adalah sebagai alam pendidikan pertama (Ahmadi dan Uhbiyati, 2003 : 178).

Dalam melaksanakan penelitian ini, penulis juga menemukan beberapa penelitian sebelumnya yang ternyata memiliki kemiripan/relevan dengan penilitian yang sedang penulis kerjakan. Namun tentu saja ada beberapa hal yang membedakannya. Adapun penelitian yang relevan tersebut yakni, Pertama, Penelitian oleh Nurhayati, dengan judul : Peranan Orang Tua dalam Mendidik Anak Berpakaian Muslimah (Studi Kasus) di Desa Kampung Pinang Kecamatan Perhentian Raja Kabupaten Kampar. Dari hasil penelitian tersebut dapat diketahui bahwa : Peranan Orang Tua dalam Mendidik Anak Berpakaian Muslimah (Studi Kasus) di Desa Kampung Pinang Kecamatan Perhentian Raja Kabupaten Kampar adalah "Kurang".

Kedua, penelitian oleh Firdaus, dengan judul: Peranan Orang Tua dalam Membina Sikap Sosial Anak di MTs Pondok Pesantren Darus Sakinah Batu
Besurat Kecamatan XIII Koto Kampar Kabupaten Kampar. Dari hasil penelitian tersebut dapat diketahui bahwa : Peranan Orang Tua dalam Membina Sikap Sosial Anak di MTs Pondok Pesantren Darus Sakinah Batu Besurat Kecamatan XIII Koto Kampar Kabupaten Kampar adalah "Cukup Baik".

Ketiga, penelitian oleh Jurnita, dengan judul: Hubungan Kecerdasan Emosional Dengan Akhlak Terpuji Siswa Madrasyah Aliyah Swasta (MAS) Masmur Pekanbaru. Dari hasil penelitian tersebut dapat diketahui bahwa: Hubungan Kecedasan Emosional Dengan Akhlak Terpuji Siswa Madrasyah Aliyah Swasta Masmur Pekanbaru taraf kategiri "sedang".

Dari penelitian terdahulu di atas terlihat dengan jelas bahwa penelitian yang penulis lakukan berbeda. Nurhayati tentang Peranan Orang Tua dalam Mendidik Anak Berpakaian Muslimah (Studi Kasus) di Desa Kampung Pinang Kecamatan Perhentian Raja Kabupaten Kampar, Firdaus tentang Peranan Orang Tua dalam Membina Sikap Sosial Anak di MTs Pondok Pesantren Darus Sakinah Batu Besurat Kecamatan XIII Koto Kampar Kabupaten Kampar, dan Jurnita, tentang Hubungan Kecerdasan Emosional Dengan Akhlak Terpuji Siswa Madrasyah Aliyah Swasta (MAS) Masmur Di Pekanbaru, sedangkan penelitian yang peneliti lakukan adalah Peranan Orang Tua dalam mengembangkan kecerdasan emosional anak di Desa Petonggan Kecamatan Rakit Kulim Kabupaten Indagiri Hulu, dimana penelitian ini belum diteliti oleh peneliti sebelumnya.

Penelitian ini berkaitan dengan kosep peran orang tua dalam mengembangkan kecerdasan emosional anak di Desa Petonggan Kecamatan Rakit Kulim Kabupaten Indragiri Hulu. 
Maka untuk mengukur peran orang tua dalam mengembangkan kecerdasan emosional ada beberapa idikator yang harus dilakukan oleh orang tua, yaitu: (1) Orang tua mengajarkan cara belajar mengembangkan kesadaran diri pada anak; (2) Orang tua mengajarkan cara belajar mengambil keputusan pribadi pada diri anak; (3) Orang tua mengajarkan cara belajar menelola perasaan pada diri anak; (4) Orang tua mengajarkan cara belajar menangani stres pada diri anak; (5) Orang tua mengajarkan cara belajar berempati pada diri anak; (6) Orang tua mengajarkan cara belajar berkomunikasi pada diri anak; (7) Orang tua mengajarkan cara belajar membuka diri pada diri anak; (8) Orang tua mengajarkan cara belajar mengembangkan pemahaman pada diri anak; (9) Orang tua mengajarkan cara belajar menerima diri sendiri pada diri anak; (10) Orang tua mengajarkan cara belajar mengembangkan tanggung jawab pribadi pada diri anak; (11) Orang tua mengajarkan cara belajar mengembangkan ketegasan pada diri anak; (12) Orang tua mengajarkan cara memplajari dinamika kelompok pada anak; dan (13) Orang tua mengajarkan cara belajar menyelesaikan konflik pada diri anak.

Berdasarkan teori di atas maka digambarkan konsep operasional yaitu belajar mengembangkan kesadaran diri, belajar mengambil keputusan pribadi, belajar mengelola perasaan, belajar menangani stres, belajar berempati, peran Orang Tua dalam Mengembangkan Kecerdasan Emosional Anak, belajar berkomunikasi, belajar membuka diri, belajar mengembangkan pemahaman, belajar menerima diri sendiri, belajar mengembangkan tanggung jawab pribadi, belajar mengembangkan ketegasan, mempelajari dinamika kelompok, dan belajar menyelesaikan konflik.

\section{METODE}

Berdasarkan pembahasan dan penjelasan di bab sebelumnya, maka jenis penelitian ini adalah penelitian deskriptif, yang menjelaskan tentang bagaimana Peranan Orang Tua dalam Mengembangkan Kecerdasan Emosional Anak di Dusun IV Desa Petonggan Kecamatan Rakit Kulim Kabupaten Indragiri Hulu?

Penelitian deskriptif adalah penelitian yang ingin mengetahui sesuatu. Maksud mengetahui keadaan sesuatu, mengenai apa dan bagaimana, berapa banyak, sejauh mana dan sebagainya, maka penelitian ini bersifat deskriptif yaitu menjelaskan atau menerangkan peristiwa (Prasetio dan Jannah, $2005:$ 42-43).

Tempat penelitian berlokasi di Dusun I, Dusun II, dan IV Desa Petonggan Kecamatan Rakit Kulim Kabupaten Indragiri Hulu. Sedangkan waktu penelitian ini dimulai dari bulan Maret 2016 sampai dengan bulan Juni 2016.

Subjek dalam penelitian ini adalah seluruh orang tua yang mempunyai anak mulai dari usia 7-14 tahun di Dusun I, Dusun IV, dan Dusun V Desa Petonggan Kecamatan Rakit Kulim Kabupaten Indragiri Hulu. Adapun yang menjadi objek penelitian ini adalah Peranan Orang Tua dalam Mengembangkan Kecerdasan Emosional Anak di Dusun I, Dusun IV, dan Dusun V Desa Petonggan Kecamatan Rakit Kulim Kabupaten Indragiri Hulu.

Populasi dalam penelitian ini adalah seluruh orang tua yang mempunyai anak mulai dari usia 7-14 tahun di Dusun I, Dusun IV, dan Dusun V Desa Petonggan Kecamatan Rakit Kulim Kabupaten Indragiri Hulu yang berjumlah 122 KK. Karena besarnya jumlah populasi dalam penelitian ini, maka peneliti mengambil $61 \mathrm{KK}$ dari berjumlah populasi yaitu sebanyak 112 kepala keluarga sebagai sampel. 
Untuk memperoleh data yang dibutuhkan dalam penelitian ini, maka penulis menggunakan teknik sebagai berikut: (1) Data primer yaitu data yang diperoleh atau dikumpulkan oleh peneliti secara langsung dari sumber datanya. Untuk mendapatkan data primer adalah dengan cara penyebaran quesioner atau angket. Angket yaitu pengumpulan data dengan memuat daftar pernyataan yang nantinya dijawab oleh orang tua; dan (2) Data sekunder yaitu data yang diperoleh atau dikumpulkan peneliti dari berbagai sumber yang telah ada, yang diperoleh dari kantor desa yang berkenaan dengan jumlah penduduk, dan dari berbagai literatur lainnya.

Teknik pengolahan data penelitian yang dilakukan melalui beberapa tahap yaitu : (a) Penyunting (Editing), yaitu tindakan mengoreksi atau melakukan pengecekan data apakah terdapat kekeliruan-kekeliruan dalam pengambilan atau pengisian data. Dengan demikian akan memperoleh data yang valid dan tepat serta dapat dipertanggung jawabkan;

Pengkodean (Coding), yaitu dengan cara memberikan tanda, kode, symbol, terhadap data yang dikategorikan sama; dan (c) Tabulasi (Tabulating), yaitu jawaban-jawaban yang serupa dikelompokkan dengan cara yang diteliti dan teratur, kemudian dihitung, diteliti dan dijumlahkan berapa banyak peristiwa, gejala, items, yang termasuk ke dalam satu kategori (Dairy, 2012 : 77-80).

Teknik analisis data yang digunakan dalam penelitian ini adalah teknik deskriptif kuantitatif yaitu menggambarkan data yang berwujud angka-angka hasil perhitungan dan pengukuran dapat diproses melalui cara dijumlahkan. Dalam penelitian ini ditetapkan penyajian data dengan penilaian dalam kategori yaitu: (1) Peranan orang tua dikatakan "sangat baik" apabila persentase $81 \%$ 100\%; (2) Peranan orang tua dikatakan "baik" apabila persentase antara 61\% 80\%; (3) Peranan orang tua dikatakan "sedang" apabila persentase antara 41\% - 60\%; (4) Peranan orang tua dikatakan "buruk" apabila persentase antara 21\% - 40\%; dan (5) Peranan orang tua dikatakan "buruk sekali" apabila persentase antara 0\% - 20\% (Ridwan dan Akdon, 2013 :17-18).

\section{HASIL}

\section{Gambaran Umum Desa Petonggan}

Desa Petonggan adalah nama suatu wilayah di Kecamatan Rakit Kulim Kabupaten Indragiri Hulu. Menurut keterangan dari tokoh masyarakat, tokoh adat dan ninik mamak setempat, desa Petonggan telah ada sejak lama, sejak Desa masih bernama kampung, yaitu sejak masa pemerintahan Presiden Soekarno dan pada waktu itu Desa Petonggan dikepalai atau dipimpin oleh Penghulu yang bernama Doghih yaitu pada tahun 1897. Sebagai gambaran awal, Desa Petonggan memiliki dua buah pulau yang sangat sederhana dan dilingkari oleh Sungai batang kuantan (Sei Indragiri). Maka Desa Petonggan dikenal orang sebagai Desa Kuantan tiga, maka tercipta didalam sebuah pantun yaitu, "Desa Petonggan Kuantannya tiga, Airnya deras hanyut ketepi, Dengan orang Petonggan walaupun lama tidak berjumpa, tapi tetap terkenang didalam hati."

Desa Petonggan Terdapat banyak aliran anak sungai yaitu: Sungai Maliki, Sungai Air Gemuruh, Sungai Antui dan Saungai Malapari. Dan memiliki lingkup kekuasaan bujur sangkar $\pm 3 \mathrm{KM}$ dan diberi perbatasan. Ketimur berbatas dengan Desa Batusawar, Kebarat Barbatas dengan Desa Lubuk Sitarak, Keutara Barbatas dengan Desa Dusun tua yang dibatasi oleh Sungai Batang 
Kuantan (Sei Indragiri) dan keselatan barbatas dengan Desa Talang Perigi.

Desa Petonggan Semenjak dari Pemerintahan Penghulu Doghih yaitu dari tahun 1897 sampai dengan sekarang sudah tiga belas orang pergantian Penghulu (Pemimpin), begitu juga dengan perkembangan dan perubahan-perubahan serta kejadiankejadian, mulai dari yang baik maupun sampai kepada kejadian yang buruk semua itu sudah pernah dirasakan. Sebagai mana dijelaskan dalam sejarah Perkembangan Desa.

Desa Petonggan terletak di dalam wilayah Kecamatan Rakit Kulim dan menjadi Ibu kota Kecamatan Rakit Kulim Kabupaten Iondragiri Hulu yang berbatasan dengan: (a) sebelah Utara Berbatasan Dengan Desa Dusun Tua Kecamatan Kelayang; (b) sebelah Timur Berbatasan Dengan Desa Batusawar Kecamatan Rakit Kulim; (c) sebelah Selatan Berbatasan Dengan Desa Tl.Gedabu dan Desa Tl.Perigi Kecamatan Rakit Kulim; dan (d) sebelah Barat Berbatasan Dengan Desa Lubuk Sitarak Kecamatan Rakit Kulim.

Luas wilayah Desa Petonggan adalah 900 Ha dimana $65 \%$ berupa daratan yang dimanfaatkan untuk areal Perkebunan Karet dan Kelapa sawit dan dikiri kanan jalan dijadikan untuk pemukiman (Lokasi Rumah) Penduduk, dan $35 \%$ dataran rendah yang mudah terkena Banjir jika musim penghujan yang dimanfaatkan untuk lahan Pertanian Padi dan palawija, dan dikiri kanan jalan juga dijadikan untuk pemukiman (Lokasi Rumah) Penduduk.

Iklim Desa Petonggan, sebagai mana desa-desa lain diwilayah Indonesia mempunyai Iklim Kemarau dan Penghujan, hal tersebut mempunyai pengaruh langsung terhadap pola tanam pada lahan Pertanian yang ada di Desa Petonggan Kecamatan Rakit Kulim.
Desa Petonggan pada saat ini berasal dari berbagai daerah yang berbeda-beda, dimana mayoritas penduduknya yang paling dominan adalah Suku Melayu Riau, dan selain dari pada itu ada yang dari Jawa Tengah, Jawa Barat, Bengkulu, Medan dan Aceh. Namun mengenai tradisi musyawarah untuk mufakat, gotong royong dan kearipan lokal yang lain sudah dilakukan oleh masyarakat sejak adanya Desa Petonggan dan hal tersebut secara efektif dapat menghindarkan adanya benturan-benturan antar kelompok masyarakat.

Visi adalah suatu gambaran yang mendatang tentang keadaan masa depan yang di inginkan dengan melihat potensi dan kebutuhan Desa. Penyusunan Visi Desa Petonggan ini dilakukan dengan pendekatan partisipatif, melibatkan pihak-pihak yang berkepetingan di Desa Petonggan seperti Pemerintah Desa, BPD, Tokoh Masyarakat, Tokoh Agama, Lembaga Masyarakat Desa dan Masyarakat Desa pada umumnya. Dengan mempertimbangkan kondisi Internal dan external di Desa sebagai satu satuan kerja kerja wilayah pembangunan di Kecamatan, maka Visi Desa Petonggan adalah : "MEWUJUDKAN KESEJAHTERAAN MASYARAKAT YANG BERMARTABAT AGAMIS DAN MENDIRI SERTA MENGEMBANGKAN POTENSI SUMBER DAYA ALAM DAN SUMBER DAYA MANUSIA“

Selain penyusunan Visi juga telah ditetapkan misi-misi yang memuat sesuatu pernyataan yang harus dilaksanakan oleh Desa agar tercapainya Visi Desa tersebut. Visi berada di atas Misi. Pernyataan Visi kemudian di jabarkan kedalam Misi agar dapat di Opersionalkan/ dikerjakan. Ada pun Misi Desa Petonggan adalah: (1) mengembangkan dan meningkatkan hasil pertanian masyarakat; (2) pembuatan sarana 
jalan usaha tani dan peningkatan jalan lingkungan; (3) peningkatan sarana air bersih bagi masyarakat; (4) perbaikan dan peningkatan layanan sarana kesehatan dan umum; (5) peningkatan saranadan prasarana dan meningkatkan

keterampilan serta kwalitas SDM masyarakat; (6) pengadaan permodalan untuk usaha kecil, memperluas lapangan kerja dan managemen usaha masyarakat; (7) peningkatan kapasitas aparat desa dan BPD; (8) peningkatan sarana dan prasarana kerja aparat desa dan BPD; dan (9) peningkatan hasil karya masyarakat.

Desa Petonggan mempunyai jumlah Penduduk untuk saat ini 1.564 jiwa, yang terdiri dari laki - laki : 840 jiwa, dan Perempuan : 724 orang dan $396 \mathrm{KK}$, yang terbagi dalam 5 (Lima) wilayah Dusun, yang penulis teliti di Dusun I, Dusun IV, dan Dusun V tersebut terdiri dari Dusun I, 1 RW 4 RT, jumlah pendudukya 316 jiwa yang terdiri dari 47 KK, Dusun IV terdiri dari 1 RW 3 RT, jumlah penduduknya 247 jiwa yang terdiri dari $42 \mathrm{KK}$, dan Dusun V terdiri dari 2 RW 3 RT, jumlah penduduknya 260 jiwa yang terdiri dari $42 \mathrm{KK}$, dan yang memiliki anak yang berusia 7-14 tahun dari tiga Dusun tersebut berjumlah $122 \mathrm{KK}$.

Adapun tingkat pendidikan masyarakat Desa Petonggan pada tahun
2016 yakni Pra-sekolah sebanyak 1.031 orang, SD sebanyak 367 orang, SLTP sebanyak 79 orang, SLTA sebanyak 54 orang dan sarjana sebanyak 33 orang. Karena Desa Petonggan merupakan Desa Pertanian maka sebagian besar penduduknya bermata pencaharian sebagai petani, yakni terdiri dari 310 KK. Sedangkan mata pencaharian lainnya seperti pedagang yakni sebanyak $35 \mathrm{KK}$, PNS sebanyak 18 KK dan buruh sebanyak $30 \mathrm{KK}$.

\section{Peranan Orang Tua Dalam Mengem- bangkan Kecerdasan Emosional Anak usia 7-14 tahun}

Pada penjelasan sebelumnya, penulis telah menjelaskan bahwa yang menjadi tujuan penelitian ini adalah untuk mengetahui Peran Orang Tua Dalam Mengembangkan Kecerdasan Emosional Anak di Dusun 1, Dusun IV, dan Dusun V Desa Petonggan Kecamatan Rakit Kulim Kabupaten Indragiri Hulu.

Untuk mendapatkan data yang diperlukan penulis menggunakan alat pengumpul data yaitu berupa angket yang diberikan kepada orang tua di Dusun 1, Dusun IV, dan Dusun V Desa Petonggan Kecamatan Rakit Kulim Kabupaten Indragiri Hulu. Untuk lebih jelasnya dapat dilihat pada tabel rekapitulasi olah angket di bawah ini : 
Tabel 1 : Rekapitulasi Jawaban Responden Tentang Peran Orang Tua Dalam Mengembangkan Kecerdasan Emosional Anak di Desa Petongggan Kecamatan Rakit Kulim Kabupaten Indragiri Hulu

\begin{tabular}{|c|c|c|c|c|c|c|c|c|c|}
\hline \multirow{3}{*}{ N 0} & \multirow{3}{*}{ TABEL } & \multicolumn{6}{|c|}{ Alternatif Jawaban } & \multirow{2}{*}{\multicolumn{2}{|c|}{ JUMLAH }} \\
\hline & & \multicolumn{2}{|c|}{$\mathbf{S}$} & \multicolumn{2}{|c|}{ KD } & \multicolumn{2}{|c|}{ TP } & & \\
\hline & & $\mathbf{F}$ & $\mathbf{P} \%$ & $\mathbf{F}$ & F\% & $\mathbf{F}$ & $\mathbf{P} \%$ & $\mathbf{F}$ & $\mathrm{P} \%$ \\
\hline 1 & 1 & 15 & $24,6 \%$ & 45 & $73,8 \%$ & 1 & $1,6 \%$ & 61 & $100 \%$ \\
\hline 2 & 2 & 11 & $18 \%$ & 47 & $77 \%$ & 3 & $5 \%$ & 61 & $100 \%$ \\
\hline 3 & 3 & 24 & $39,3 \%$ & 34 & $55,8 \%$ & 3 & $4,9 \%$ & 61 & $100 \%$ \\
\hline 4 & 4 & 13 & $21,3 \%$ & 45 & $73,8 \%$ & 3 & $4,9 \%$ & 61 & $100 \%$ \\
\hline 5 & 5 & 24 & $39,3 \%$ & 37 & $60,7 \%$ & 0 & 0 & 61 & $100 \%$ \\
\hline 6 & 6 & 47 & $77,1 \%$ & 14 & $22,9 \%$ & 0 & 0 & 61 & $100 \%$ \\
\hline 7 & 7 & 30 & $49,1 \%$ & 31 & $50,9 \%$ & 0 & 0 & 61 & $100 \%$ \\
\hline 8 & 8 & 11 & $18 \%$ & 50 & $82 \%$ & 0 & 0 & 61 & $100 \%$ \\
\hline 9 & 9 & 18 & $29,5 \%$ & 43 & $70,5 \%$ & 0 & 0 & 61 & $100 \%$ \\
\hline 10 & 10 & 21 & $34,4 \%$ & 40 & $65,6 \%$ & 0 & 0 & 61 & $100 \%$ \\
\hline 11 & 11 & 12 & $19,7 \%$ & 49 & $80,3 \%$ & 0 & 0 & 61 & $100 \%$ \\
\hline 12 & 12 & 6 & $9,9 \%$ & 53 & $86,9 \%$ & 2 & $3,3 \%$ & 61 & $100 \%$ \\
\hline 13 & 13 & 4 & $6,6 \%$ & 56 & $91,8 \%$ & 1 & $1,6 \%$ & 61 & $100 \%$ \\
\hline & LAH & 236 & - & 544 & - & 13 & - & 793 & $100 \%$ \\
\hline
\end{tabular}

Dari hasil rekapitulasi dapat diketahui bahwa total jawaban sering oleh responden adalah 236 kali, jawaban kadang-kadang 544 kali dan jawaban tidak pernah 13 kali. Dari hasil ini berarti total jawaban responden secara keseluruhan adalah 793 kali. Hasil yang tercantum dalam tabel akan membantu penulis untuk melihat secara keseluruhan total jawaban responden padaa tiap-tiap pernyataan yang ada pada angket.

Untuk memudahkan penulis dalam mengolah data, maka terlebih dahulu penulis memberi kode pada pilihan jawaban hasil angket adapun kodenya sebagai berikut : untuk jawaban sering diberi kode option S, untuk jawaban kadang- kadang penulis beri kode KD dan untuk jawaban tidak pernah penulis beri kode option TP.

\section{PEMBAHASAN}

Berdasarakan hasil rekapitulasi hasil angket yang disebarkan jelas terlihat pada tabel 18, diperoleh jumlah frekuensi jawaban "sering" 236, jumlah frekuensi "kadang-kadang" 544, dan jumlah frekuensi "tidak pernah" 13.

Selanjutnya untuk memberikan penilaian dari tiap-tiap jawaban diberikan skor sebagai berikut: (a) Jika sering (S) diberi skor 3; (b) Jika kadang- 
kadang (KD) diberi skor 2; dan (c) jika tidak Pernah (TP) diberi skor 1.

Berdasarkan skor tersebut dapat dinilai secara keseluruhan hasil rekapitulasi tabel angket diatas, maka diperoleh angka masing-masing jawaban sebagai berikut :

\begin{tabular}{ll} 
1. Alternatif jawaban S & $=708$ \\
2. Alternatif jawaban KD & $=1088$ \\
3. Alternatif jawaban TP & $=13$ \\
\hline Jumlah F F & $=1809$
\end{tabular}

Dengan demikian jumlah keseluruhan dari angket Peran Orang Tua Dalam Mengembangkan Kecerdasan Emosional Anak di Desa Petonggaan Kecamatan Rakit Kulim Kabupaten Indragiri Hulu tersebut sebagai berikut :

$\mathrm{P}=\frac{F}{N} \times 100 \%$

Ket : $\mathrm{N}$ adalah skor ideal atau skor maksimal yang akan didapat jika seluruh responden menjawab sering pada tiap-tiap pernyataan. Total jumlah responden untuk 1 item pernyataan pada angket berjumlah 61 sedangkan jumlah item adalah 13. Untuk mengetahui total jumlah redponden pada penelitian ini ialah dengan cara menjumlahkan seluruh responden yang menjawab 13 item maka hasilnya adalah $61 \times 13=793$. Sedangkan untuk mendapatkan nilai N ( nilai ideal jawaban seluruh responden) ialah dengan cara mengkalikan jumlah responden dengan jawaban yang kita jadikan alat ukur dalam menentukan keidealan sesuatu. Adapaun alat ukur keidealan tersebut yang penulis gunakan adalah jawaban sering dalam penelitian ini. Dikarenakan setiap jawaban sering penulis beri skor 3 . Berdasarkan hal tersebut maka nilai $\mathrm{N}$ adalah $793 \times 3=2379$.
Maka hasil $\mathrm{F}$ dan $\mathrm{N}$ yaitu $: \mathrm{F}=1809$

$\mathrm{N}=793 \times 3=2379$

$\mathrm{P}=\frac{F}{N} \times 100 \%$

Jadi, $P=\frac{1809}{2379} \times 100 \%=76,04 \%$

\begin{tabular}{cccc}
\multicolumn{2}{c}{ Maka, dapat diketahui } & bahwa \\
Peran & Orang & Tua & dalam
\end{tabular} Mengembangkan kecerdasan Emosional Anak di Desa Petonggan Kecamatan Rakit Kulim Kabupaten Indragiri Hulu berada pada titik 76,04 \%. Untuk mengukurnya sesuai dengan hasil rujukan pada patokan yang telah di tetapkan sebelumnya yaitu: (1) Peran orang tua dikatakan "sangat baik" apabila presentase 81\%- 100\%; (2) Peran orang tua dikatakan 'baik' apabila presentase antara $61 \%$ - $80 \%$; (3) Peran orang tua dikatakan "sedang" apabila presentase antara $41 \%$ - $60 \%$; (4) Peran orang tua dikatakan "buruk" apabila presentase antara $21 \%$ - $40 \%$; dan (5) Peran orang tua dikatakan "buruk sekali" apabila presentase antara $0 \%-20 \%$ (Ridwan dan Akdon, 2013 : 17-18).

Dengan demikian, berdasarkan rekapitulasi hasil penyajian di atas dapat disimpulkan bahwa Peran Orang Tua Dalam Mengembangkan Kecerdasan Emosional Anak Di Desa Petonggagan Kecamatan Rakit Kulim Kabupaten Indragiri Hulu berada pada taraf "Baik" yaitu berada pada rentang $61 \%$ - 80 \% dikategorikan "Baik".

\section{SIMPULAN}

Berdasarkan analisis data yang telah dipaparkan dapat disimpulkan bahwa bahwa Peran Orang Tua Dalam Mengembangkan Kecerdasan Emosional Anak Di Desa Petonggagan Kecamatan

Rakit Kulim Kabupaten 
Indragiri Hulu diktegorikan "Baik" dengan angka presentase $61 \%$ - $80 \%$.

Berdasarkan kesimpulan di atas, maka peneliti memberikan saran-saran untuk lebih meningkatkan peran orang tua dalam mengembangkan kecerdasan emosional anak sebagai berikut: (1) Kepada orang tua hendaknya lebih meningkatkan perhatiannya kepada anak; (2) Memahami emosi dengan menyelami apa yang telah dirasakan anak dengan menempatkan diri dalam posisi anak dan berusaha memandang dari sudut pandang anak, lalu mendengarkan dengan empati sebagai salah satu upaya dalam memberikan dukungan terhadap apa yang dirasakan anak; (3) Setiap anggota keluarga hendaknya turut mendorong anak untuk lebih bisa mengendalikan emosinya, karena hanya pihak keluargalah yang besar peranannya dalam membina dan membentuk kepribadian seorang anak; dan (4) Hendaknya para anggota keluarga selalu berusaha supaya semua pengaruh yang diberikannya kepada perkembangan anak mempunyai pengaruh yang positif.

Selain itu, pendidikan nonformal merupakan salah satu pendidikan yang didalamnya mengkaji tentang pendidikan anak, dimana pendidikan tersebut sebagai langkah awal dalam pembentukan kecerdasan anak baik dari segi intelektual maupun emosional, karena itu pendalaman mengenai kecerdasan emosi sangat penting dikaji, disampaikan, dibahas dalam bentuk materi pendidikan.

\section{DAFTAR RUJUKAN}

Al-Migwar. 2006. Psikologi Remaja. Bandung : Pustaka Setia Group.

Darajat, Zakiah dkk., 2009. Ilmu Pendidikan Islam. Jakarta : PT. Bumi Aksara.
Departemen Agama RI. 2002. Al quran dan Terjemahan. Semarang : PT. Karya Toha Putra.

Djali. 2012. Psikologi Pendidikan. Jakarta : PT. Bumi Aksara.

Djmarah, Syaiful Bahri. 2004. Pola Komunikasi Orang tua dan Anak Dalam Keluarga. Jakarta : PT Rineka Cipta.

Ihsan, Fuad. 2005. Dasar Dasar Pendidikan Islam. Jakarta : PT. RINEKA CIPTA.

Kamus Besar Bahasa Indonesia Pusat Bahasa. 2013. Edisi keempat. Jakarta: Gramedia Pustaka Utama.

Latipah, Eva. 2012. Pengantar Psikologi Pendidikan. Yogyakarta : PT. Pustaka Insani.

Nata, Abuddin. 2010. Ilmu Pendidikan Islam. Jakarta : Kencana Prenada Media.

Nurihsan, Achmat Juntika dan Agustin, Mubiar. 2011. Dinamika Perkembangan Anak dan Remaja, Tinjauan Psikologi, Pendidikan, dan Bimbingan. Bandung : PT. Refika Aditama.

Purwanto, Ngalim. 2011. Ilmu Pendidikan Teoretis dan Praktis. Bandung: PT. Remaja Rosdakarya Ramayulis. 2008. Ilmu Pendidikan Islam. Jakarta : Kalam Mulia Riduan, Akdon, 2013 : Rumus dan Data Dalam Analisis dan Statistika. Bandung : Alfabeta.

Shochib, Moch., 2010. Pola Asuh Orang Tua Dalam membantu Anak Mengembangkan Disiplin Diri Sebagai Pribadi yang Berkarakter. Jakarta : PT Asdi Mahasatya.

Sudiyono. 2009. Ilmu Pendidikan Islam. Jakarta : PT. Rineka Cipta.

Tambak, Syahraini. 2013. Pendidikan Komunikasi Islam. Jakarta : Kalam Mulia.

Yusuf, Syamsu. 2011. Psikologi Perkembangan Anak Dan Remaja. Bandung : PT. Remaja Rosdakarya. 